\title{
Affect-Adaptive Activities in a Personalised Ubiquitous Learning System
}

\author{
O. S. Adewale, O. C. Agbonifo, E. O. Ibam, A. I. Makinde, \\ O. K. Boyinbode, B. A. Ojokoh and O. Olabode \\ Department of Computer Science, School of Computing, The \\ Federal University of Technology, Akure, Nigeria
}

\section{S. Omirin and S. O. Olatunji}

Ekiti State University, Ado - Ekiti, Nigeria

\begin{abstract}
Many literatures have shown the importance of emotion in learning because of their effect on learner's performances thereby giving reasons why learners' affective states are crucial to learning. In this light, this research work aims to identify affect-adaptive activities that would improve learning in a personalised ubiquitous learning system by detecting learning style and affective states through some patterns of behaviours. In the study, learners' preference are determined, learners affective states such as confidence, effort, independence and confusion are investigated. The ant colony clustering algorithm is used to determine learners' activities. The four affective states are determined from the learners' forum threads, content activities, assessment, timing, and discussion through learners' engagement. The result of this research on two separate courses, Course A (Affect) and Course B (Non-Affect) shows that the four affective states influence learning. The average mean and standard deviation (SD) value for Course A (Mean=276.23, $\mathrm{SD}=272.27)$ over Course B (Mean=200.58, SD=210.51) showed an improvement in learning performance and the $t$-Test carried out between the courses suggested that students' performance is dependent on their affective states.
\end{abstract}

Keywords: affective states; adaptive; ubiquitous; learning; learning styles; activities.

\section{Introduction}

The numerous developmental phases of information technology have transformed education system in recent years. This development gave access to global communications and resources available to today's students at all levels of schooling (Yaun et al., 2013; Jones \& Jo, 2004). 
Learning styles make it possible to assign the preferred ways of learning. Whenever a learner with a unique learning style is not supported by any teaching environment, it makes learning difficult for such a learner (Kirschner et al., 2006; Felder \& Silverman, 1988). For instance, learner learns more when the instruction presented correspond to their learning style (Entwistle \& Ramsden, 2015). The best method for getting learning style which is based on instructional material in large classes is through adaptive e-learning environment as this does not have the common limitations face to face scenario has which focus on individual students due to the lack of required resources and time (Wanner \& Palmer, 2015).

The application of ubiquitous computing in education known as ubiquitous learning (u-learning) marks a great step forward in the delivery of education instruction materials. The u-learning has revolutionized education and overcome some of the constraints of traditional learning. However, learning using the same learning content will lead to a cognitive mismatch. The integration of adaptive learning and ubiquitous computing may offer great innovation in the delivery of learning, granting access to personalization and customization to student needs (Sung et al., 2016; Kim, 2006).

Furthermore, in a traditional learning environment, a teacher finds it difficult to teach all learners' individually due to a large number of the learners. However, the teacher can monitor and draw conclusions from students' learning behaviour which can be referred to as learners' affective states. A learning system that considers learner's affective state will improve and therefore enhances a learner's learning experience (Baker et al., 2010).

Several parameters such as anger, fear, joy, surprise, disgust, motivation, interest, proclivity, confidence, confusion, and effort have been used to describe learners' affective states (Khan et al., 2010; Qu et al., 2005; Lopatovska \& Arapakis, 2011). Affect has been shown to influence the learning process (Kort et al. 2001; D'Mello et al. 2014; Baker et al. 2010).

Affective states can be classified into two, the positive affective states and the negative affective states. The positive affective states such as confidence, satisfaction and so on contribute towards learnings while the negative affective states inhibit learning. Therefore, the paper investigates the effect of adaptivity, personalisation, ubiquity and affective states on students' learning.

\section{Literature Review}

With the emergence of ubiquitous learning (u-learning), access to education by students have become flexible, and seamless. The definition of $\mathrm{u}$-learning can be broadly classified into three categories: the adopted technologies, the education objects and the learning process (Peña-Ayala \& Cárdenas, 2016). In a definition influenced by the classification of learning environments, ulearning was described as a combination of the e-learning and m-learning paradigms (Behera, 2013). 


\section{Learning Styles}

A learner whose learning style is not supported by a particular learning environment is bound to face difficulties during learning (Entwistle \& Ramsden, 2015; Felder and Silverman, 1988). Felder and Silverman Learning Style Model (FSLSM) is one of the learning style models used in learning style related research for information technology-based learning systems. The FSLSM has been demonstrated to be most appropriate for hypermedia courseware (Tortorella \& Graf, 2017; Liyanage et al., 2016; Fasihuddin et al., 2017). FSLSM distinguishes among four different dimensions. These dimensions are active, reflective, sensing, intuitive, visual, verbal, sequential and global dimension. A combination of these dimensions makes up the learners' individuals learning preferences.

Advances in information technology have transformed greatly the practice of learning in recent years. However, learning platforms such as Moodle, Blackboard among others do not support a full-fledged adaptivity that is based on learning styles and affective states (Jones \& Jo, 2004).

\section{Adaptive Learning}

Adaptive learning can be referred to a concept that learning methodologies to learners' individuals learning styles. Some of the elements of adaptive learning has been demonstrated to include: monitoring activity, interpreting the results, understanding requirements and preferences, and facilitated learning process with gained information (Zimmerman, 2013; Paramythis \& Loidl-Reisinger, 2004).

This type of learning system offers a great advantage in providing learners with specific and personalised knowledge during learning. The use of adaptive strategies can be dated back as early as the start of the twentieth century as educators began to look for other means to improve the learning outcomes of student understanding and learning (Moore \& Kearsley, 2011; Zimmerman, 2013). The development of such systems will definitely provide or support effective learning experiences for a different type of learners across a broader view of knowledge domains. Therefore, adaptive learning systems are to feature learner preferences, interests, learning contents, and browsing behaviours to provide adaptive and personalised learning services (Premlatha, 2016; Wang et al., 2017; Beldagli \& Adiguzel, 2010).

\section{Personalised Learning}

Personalised learning allows learners' specific requirements to be identified and addressed during a learning process. Advances in information technology enable teachers to develop rapidly personalised learning instruction materials and utilise real-time data for a feedback mechanism. This learning paradigm promotes learner's choice in his education. It closes the gaps in the individual learner, learning styles and provides the needed support to succeed in his/her education. In this paradigm, teachers become mentors or facilitators while learners have controls over what, how and where they learn. 


\section{Ubiquitous Learning}

With the emergence of ubiquitous learning (u-learning), access to education by students have become flexible, and seamless. U-learning has been described as a hybridisation of the best features of e-learning and m-learning paradigms (Wong et al., 2015; Casey, 2005). Therefore, u-learning is a learning paradigm that enables learning what is necessary at the right place and time in the right way (Yahya et al., 2010). This learning paradigm was made possible due to the availability of mobile, wireless communication and sensing technologies (Hsu et al., 2016) which can support real-world contexts learning (Yin et al., 2016). This learning paradigm has been described as the context-aware ubiquitous learning or contextual mobile learning (Brown \& Mbati, 2015; Chen \& Huang, 2012; Hwang et al., 2008).

\section{Affective Computing}

Affective computing can be referred to systems and device study and development that can simulate, recognise, interpret, and process human affects (Becker-Asano \& Wachsmuth, 2010; Picard, 1997). Haijan et al. (2017) proposes a study based on learner's interest and emotion recognition to effectively construct affective education to optimise and enhance the teaching effectiveness. Learner's voice, text and behaviour extraction was carried out using Semantic Orientation-Pointwise Mutual information. Research on recognising emotion has made great progress since affective computing was proposed by Professor Picard in 1997 (Picard, 1997).

According to Kalyuga (2011), affective computing has been a fundamental element in designing and developing adaptive learning systems. This is due to the fact that learning process is complex (Bennet \& Bennet, 2008) and involves students' cognitive activities and emotions. Therefore, many researchers suggested that effective and meaningful learning can be achieved when students have positive cognitive as well as emotional states during learning. From eLearning perspective, students' emotions will ensure the effectiveness of a learning process (López-Pérez et al., 2011; Khan, Weippl, \& Tjoa, 2009).

Different methods for detection of emotion are the use of biophysical signals, speech signals, facial expressions, machine learning techniques applied on learners' preferences and behaviours in the systems, different text-based method and virtual reality (Callaghan et al., 2009). The former methods though give better accuracy, are quite expensive and cumbersome and are less practical to implement in a large-scale e-learning environment, whereas, the methods like machine learning, text-based methods and virtual reality are less cumbersome and are more suitable in such scenario (Marczak et al., 2016).

However, confidence (Baker et al., 2010), effort (Zimmerman, 2013), independence (Baker, 2010) and confusion (Baker et al., 2010) have been used to identify the pattern of behaviour of the learners' affective states. These four 
affective states will be used in this paper to identify the pattern of behaviour of the learners' affective states.

\section{Methodology}

This section discusses the system architecture and models used.

\section{A. System Architecture}

Figure 1 consists of the key components of the system architecture. These include Learners location detection, learner interface, learners profile, adaptive learning system, learning resources, learning activities, affect recognition module, web server and evaluation module while the access point (AP) wireless signal is used for detecting and calculating learners' location via mobile devices.

Learner interface and learners profiles consist of a registration, login module and other personalised records which helps to extract and store learner's preferences and also affect features. The adaptive learning system helps to determine the cognitive characteristic, knowledge space and preferences.

The learners use the learner interface to interact with the adaptive system to get learning resources and participate in learning activities such as forum discussion and content outline. The learners' profiles contain the affect states and learning progress of individual learner. The adaptive system also interacts with the learning resources which are stored in a web server based on learner's profile. Learners' behaviours are captured during the learning procedure. Affect recognition module help detect what the learners' emotions are (Confidence, Effort, Independence and Confusion) which are used to improve the system.

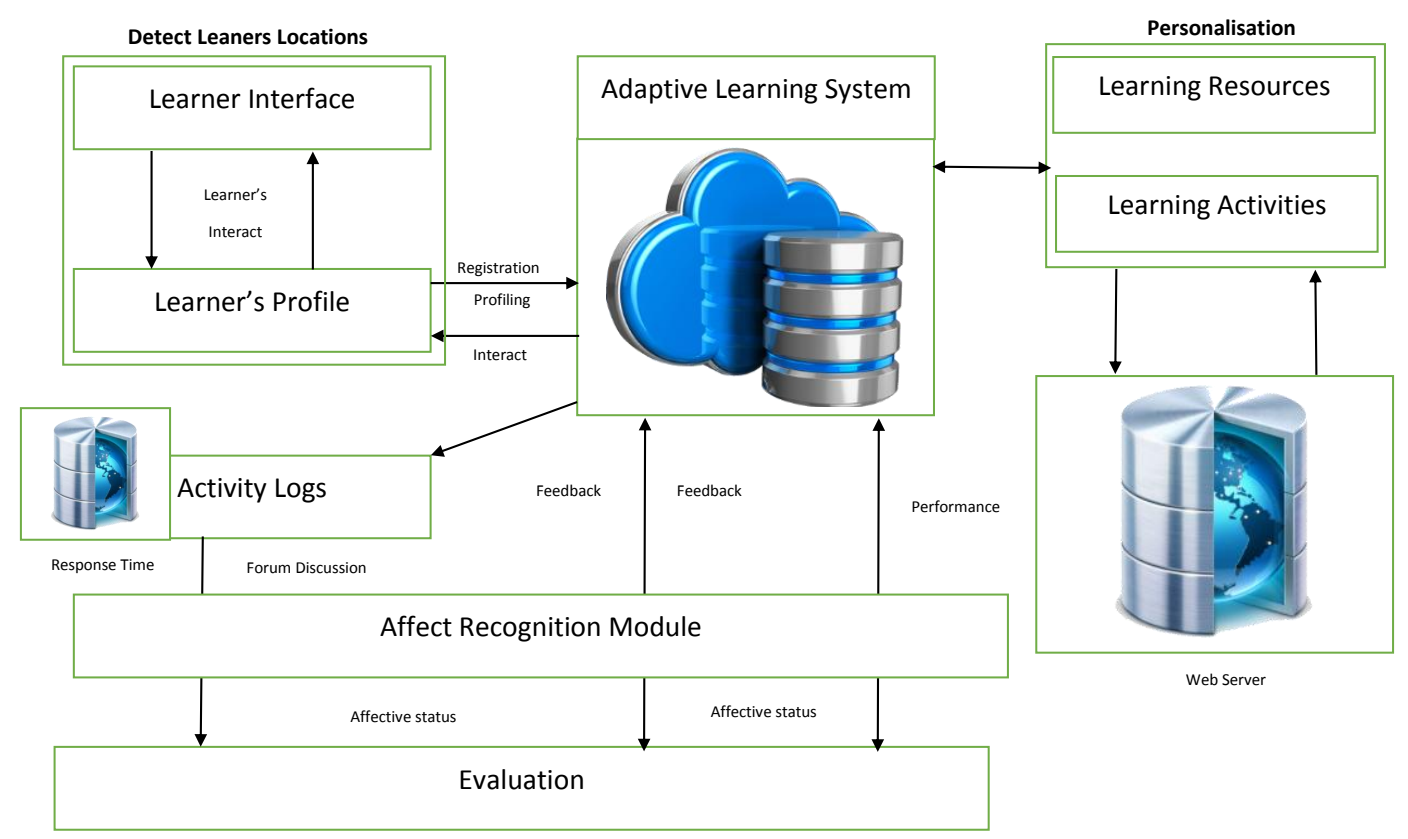

Figure 1: Affect-Adaptive System Architecture 


\section{B. Affect-Adaptive learning models Location}

In order to detect learner' location, trilateration algorithm and fingerprinting technique are employed to implement a received signal strength (RSS) based location method (Lin et al., 2014; Setiya and Gaur, 2012). Their main aim is to estimate and get the learners location by calculating the coordinates through geometry. In the geometry algorithm, at least three of the anchor node and their estimated distance from the node must be known (Ruiz et al., 2013; Doukhnitch et al., 2008). The coordinates of the three nodes are represented by $N_{1}, N_{2}$, and $N_{3}$ the distances from these three anchor nodes to node $N$ are $d_{n 1}, d_{n 2}, d_{n 3}$.

The coordinates of node $\mathrm{N}(\mathrm{x}, \mathrm{y})$ are unknown, then formulae in equation (1) is stated as follows (Sadoun \& Al-Bayari, 2007):

$$
\begin{aligned}
& d_{\mathrm{n} 1}=\sqrt{\left(\mathrm{x}-\mathrm{x}_{\mathrm{n} 1}\right)^{2}+\left(\mathrm{y}-\mathrm{y}_{\mathrm{n} 1}\right)^{2}} \\
& \mathrm{~d}_{\mathrm{n} 2}=\sqrt{\left(\mathrm{x}-\mathrm{x}_{\mathrm{n} 2}\right)^{2}+\left(\mathrm{y}-\mathrm{y}_{\mathrm{n} 2}\right)^{2}}
\end{aligned}
$$

$$
d_{n 3}=\sqrt{\left(x-x_{n 3}\right)^{2}+\left(y-y_{n 3}\right)^{2}}
$$

Using Equation (1), the coordinates of node $\mathrm{N}$ are calculated.

$$
\begin{aligned}
& {\left[\begin{array}{l}
\mathrm{x} \\
\mathrm{y}
\end{array}\right]=\left[\begin{array}{l}
2\left(\mathrm{x}_{\mathrm{n} 1}-\mathrm{x}_{\mathrm{n} 3}\right) 2\left(\mathrm{y}_{\mathrm{a} 1}-\mathrm{y}_{\mathrm{n} 3}\right) \\
2\left(\mathrm{x}_{\mathrm{n} 2}-\mathrm{x}_{\mathrm{n} 3}\right) 2\left(\mathrm{y}_{\mathrm{a} 2}-\mathrm{y}_{\mathrm{n} 3}\right)
\end{array}\right]^{-1} \mathrm{x}} \\
& {\left[\begin{array}{l}
\mathrm{x}_{\mathrm{n} 1}^{2}-\mathrm{x}_{\mathrm{n} 3}^{2}+\mathrm{y}_{\mathrm{n} 1}^{2}-\mathrm{y}_{\mathrm{n} 3}^{2}+\mathrm{d}_{\mathrm{n} 1}^{2}-\mathrm{d}_{\mathrm{n} 3}^{2} \\
\mathrm{x}_{\mathrm{n} 2}^{2}-\mathrm{x}_{\mathrm{n} 3}^{2}+\mathrm{y}_{\mathrm{n} 2}^{2}-\mathrm{y}_{\mathrm{n} 3}^{2}+\mathrm{d}_{\mathrm{n} 2}^{2}-\mathrm{d}_{\mathrm{n} 3}^{2}
\end{array}\right]}
\end{aligned}
$$

According to equation 2 (Lin et al., 2014),

- Trilateration algorithm is used to calculate the target point

- The radius of the three Access Points (Aps) represent the distance between the target and the corresponding APs

- Target point is the interception of the APs location.

\section{Determining Learners' Activities}

Ant colony clustering algorithm is applied to this research work for determining learners' activities, especially on learning resources. Ant colony clustering algorithm is a clustering algorithm based on ant cleaning behaviour, and the main idea is the process of transporting ants (Hu et al., 2012). Ants start-off by being placed onto graph nodes. They choose an edge to traverse from the home node depending on the pheromone levels on each edge. Since the edge will not have any pheromone yet, the ant will deposit pheromone equating to its features when leaving a node that matches one or more features. The pheromone deposition depends on the features which are present on the node and also depends on the attractiveness of the features to the ant. Hence, with each ant as an individual leaner, each learner determines the probability 
of handling an activity according to the similarity between the learning objects and the environment.

The similarity between different learning objects in the learning environment can be defined as the arithmetic mean of the probability of each attribute of the object as shown in equation (3):

$$
f\left(S_{i}\right)=1 / n \sum_{j=1}^{n} P_{i j}
$$

Where $\mathrm{n}$ represents the number of attributes of the learning objects The probability of an ant picking up can be defined as

$$
P_{p}=1-\frac{1-e^{-c f\left(S_{i}\right)}}{1+e^{-c f\left(S_{i}\right)}}
$$

While the probability of an ant dropping is defined as follows

$$
P_{d}=1-\frac{1-e^{-c f\left(S_{i}\right)}}{1+e^{-c f\left(S_{i}\right)}}
$$

$c$ is a constant that is used to adjust convergence speed, once the $c$ value is different and the function of convergence speed is different.

Table 1 and Table 2 summarise the different patterns of behaviours to recognize affective states and learning styles respectively. The patterns in Table 1 are embedded for an individual dimension of the learning style while the pattern in Table 2 incorporated for each affect-adaptive state to achieve a personalised adaptive learning system. Based on the number of occurrence of each pattern, the learners learning style, and specific affective state are determined which are then used for calculating the affective states and learning style preferences recognised.

Table 1: Patterns of behaviour to recognise learning styles

\begin{tabular}{|l|l|l|l|}
\hline Active/Reflective & Sensing/Intuitive & Visual/verbal & Sequential/global \\
\hline contntvisit(-) & contntvisit(-) & questgraphics(+) & outlinevisit(-) \\
\hline contntstay(-) & contntstay(-) & questtext(-) & outlinestay(-) \\
\hline outlinestay(-) & examplevisit(+) & contntvisit(-) & $\begin{array}{l}\text { courseovviewvis } \\
\text { it(-) }\end{array}$ \\
\hline $\begin{array}{l}\text { forumcontntpost } \\
(+)\end{array}$ & examplestay(+) & contntstay(-) & $\begin{array}{l}\text { courseovviewsta } \\
\text { y(-) }\end{array}$ \\
\hline $\begin{array}{l}\text { forumcontntpost } \\
\text { reply(+) }\end{array}$ & slfassesvisit(+) & $\begin{array}{l}\text { forumcontntp } \\
\text { ost(-) }\end{array}$ & navigationskip(-) \\
\hline $\begin{array}{l}\text { forumassignmntp } \\
\text { ostrepl(+) }\end{array}$ & slfassessstay(+) & $\begin{array}{l}\text { forumcontntpost } \\
\text { repl(-) }\end{array}$ & \\
\hline slfassessvisit (+) & exercsvisit(+) & & \\
\hline slfassessstay(-) & exercsstay(+) & & \\
\hline exercsvisit(+) & slfassessrevision(+) & & \\
\hline exercsstay(+) & assignmntrevision(+) & & \\
\hline & assignmntstay(+) & & \\
\hline
\end{tabular}


Table 2. Patterns of behaviour to recognise affective states

\begin{tabular}{|l|l|l|l|}
\hline Confidence & Effort & Independence & Confusion \\
\hline contntvisit & slfassessvisit & contntvisit & slfassessvisit \\
\hline outlinevisit & slfassessstay & outlinevisit & exercsvisit \\
\hline examplevisit & exercsvisit & examplevisit & examplevisit \\
\hline exercsvisit & exercsstay & forumcontntvisit & examplestay \\
\hline slfassessvisit & forumcontntvisit & forumcontntpost & $\begin{array}{l}\text { forumassignmntpos } \\
\text { t }\end{array}$ \\
\hline forumcontntpost & $\begin{array}{l}\text { forumcontntpostre } \\
\text { pl }\end{array}$ & $\begin{array}{l}\text { forumcontntpostrep } \\
\text { l }\end{array}$ & Assignmntrevision \\
\hline forumcontntpostreply & assignmnt revision & assignmntrevision & Contntstay \\
\hline forumassignmntvisit & & slfassessvisit & forumcontntvisit \\
\hline forumcontntvisit & & slfassessstay & $\begin{array}{l}\text { forumcontntpost } \\
\text { repl }\end{array}$ \\
\hline forumcontntpost & & slfassessrevision & \\
\hline & & exercsvisit & \\
\hline forumassignmntpostrepl & & exercsstay & \\
\hline
\end{tabular}

Graf et al. (2009) proposed an approach for calculating learning style from behavioural pattern through hints calculation. Hints are represented by four values that is $0-3$, where 0 denotes weak indication towards the respective learning style used for learning preferences. Learners' behaviour indicates average if the hint value is 2 (two), which means that a specific hit is not provided. Also, the learners' behaviour is said to be in disagreement with its learning style or affective state if the hint value is 1 . Hint value 0 indicates zero information on learners' behaviour.

To calculate learning styles and their respective affective states, equation (6) is used

$$
\frac{\sum_{i=0}^{n} x_{i}}{n} ; 0 \leq x_{i} \leq 3
$$

Where $\mathrm{x}$ represents a hint value for each patter, $\mathrm{i}$ represents pattern number and i represent number of patterns giving information.

This measure is then normalised on a range from 0 to 1 for both learning style and affective state. The value 1 represents a strong positive level and the value 0 represents a strong negative level for the particular learning style and affective state. In case no information is available for all patterns of a learning style dimension or affective state, no conclusion can be drawn.

\section{Results And Discussion}

One hundred and twenty-nine (129) learners took part in the online course. The same set of students were enrolled in two different courses lasting for about 5weeks. The two courses are course A (with affect) and course B (non- 
affect). Data were collected through online self-report including measures of emotional experience while relating with activities and resources online. The obtained data were significant for this study because it contained timestamp interaction activities recorded for each learner during learning. Data recorded such as view discussion, post discussion, resources visit, content visit and outline visit as are part of what made up the application logs. The log has 3552 activities for course A (with affect) and 2481 activities for course B (nonaffect).

Table 3 shows the breakdown of behavioural pattern capture in the system $\log$ for course A and B were patterns such as examplevisit, forumassignmntvisit and forumconentvisit has the highest percentage records. Course A has a forumcontntpostreply of 308 for two forum post while Course B has 209. Table 3 also shows that learners engaged more in activities when their affective states are considered.

Table 3: Break down of Behavioural patterns

\begin{tabular}{|l|r|r|r|r|}
\hline & \multicolumn{2}{|c|}{ COURSE A } & \multicolumn{2}{c|}{ COURSE B } \\
\hline Patterns of Behaviour & \multicolumn{1}{|c|}{ Number } & Percentage(\%) & Number & percentage(\%) \\
\hline Outlinevisit & 33 & 1 & 21 & 1 \\
\hline Contentvisit & 90 & 3 & 45 & 2 \\
\hline Contentstay & 57 & 2 & 32 & 1 \\
\hline Assignmntrevision & 24 & 1 & 2 & 0 \\
\hline Examplevisit & & & & 21 \\
\hline Exercsvisit & 213 & 6 & 530 & 5 \\
\hline Exercsstay & 322 & 9 & 23 & 0 \\
\hline Forumcontntpost & 2 & 0 & 2 & 9 \\
\hline Forumcontntpostreply & 308 & 9 & 212 & 16 \\
\hline Forumassignmntvisit & 593 & 17 & 400 & 24 \\
\hline Forumcontntvisit & 700 & 20 & 600 & 8 \\
\hline Slfassessvisit & 211 & 6 & 190 & 5 \\
\hline Slfassessstay & 133 & 4 & 121 & 0 \\
\hline Slfassessrevision & 43 & 100 & 2481 & \\
\hline TOTAL & & & & \\
\hline
\end{tabular}

\section{Response Timing.}

The observations from this Table 4 are discussed as follows: The response timing for course A with respect to Discussion 1 is that $64 \%$ of the learners responded on the due date while. $4 \%$ responded after the due date while in discussion 2 , only $2 \%$ responded after the due date. This response suggests an improvement of student understanding. In course B, there was a decrease in the number of learners that submitted their responses by due date with only $32 \%$ and $41 \%$ for both discussion 1 and discussion 2 respectively. 
Table 4: Timing of Learners Response Post

\begin{tabular}{|c|c|c|c|c|c|c|c|c|}
\hline \multicolumn{9}{|c|}{ TIMING OF LEARNERS RESPONSE POST } \\
\hline & \multicolumn{4}{|c|}{ COURSE A } & \multicolumn{4}{|c|}{ COURSE B } \\
\hline \multirow[t]{2}{*}{ Timing } & \multicolumn{2}{|c|}{ Discussion 1} & \multicolumn{2}{|c|}{ Discussion 2} & \multicolumn{2}{|c|}{ Discussion 1} & \multicolumn{2}{|c|}{ Discussion 2} \\
\hline & $\begin{array}{l}\text { Learners } \\
\text { Number }\end{array}$ & $\begin{array}{l}\% \text { of } \\
\text { Learners }\end{array}$ & $\begin{array}{l}\text { Learners } \\
\text { Number }\end{array}$ & $\begin{array}{l}\% \text { of } \\
\text { Learners }\end{array}$ & $\begin{array}{l}\text { Learners } \\
\text { Number }\end{array}$ & $\begin{array}{l}\% \text { of } \\
\text { Learners }\end{array}$ & $\begin{array}{l}\text { Learners } \\
\text { Number }\end{array}$ & $\%$ of Learners \\
\hline $\begin{array}{l}\text { Response after } \\
\text { a day }\end{array}$ & 41 & 32 & 3 & 2 & & 1 & 15 & 12 \\
\hline $\begin{array}{l}\text { Response } \\
\text { posted on due } \\
\text { date }\end{array}$ & 83 & 6 & 6 & 5 & 4 & 32 & 53 & 41 \\
\hline $\begin{array}{l}\text { Response } \\
\text { posted after due } \\
\text { date }\end{array}$ & 5 & 2 & & & 7 & 58 & 61 & 47 \\
\hline
\end{tabular}

\section{Quantity of Post}

Individual participant is expected to reply to the forum post at least once in the online forum discussion. There were about 308 valid responses for course A as shown in Table 5 and about 212 valid responses for Course B. With both Course A and Course B having an average of 2.39 posts per person and 1.64 posts per person responses respectively. Course A shows more intensity and interest of learners to participate in the online discussion when compared to course B. Course A benefitted immensely when learners' affective states are considered.

Table 5: Number of responses posted by learners of course A and course B

\begin{tabular}{|c|c|c|c|c|c|c|c|c|}
\hline \multirow{2}{*}{$\begin{array}{l}\text { Number } \\
\text { of } \\
\text { responses } \\
\text { posted }\end{array}$} & \multicolumn{2}{|c|}{$\begin{array}{l}\text { Course A } \\
\text { Discussion } 1\end{array}$} & \multicolumn{2}{|c|}{$\begin{array}{l}\text { Course B } \\
\text { Discussion } 1\end{array}$} & \multicolumn{2}{|c|}{$\begin{array}{l}\text { Course B } \\
\text { Discussion } 2\end{array}$} & \multicolumn{2}{|c|}{$\begin{array}{l}\text { Course A } \\
\text { Discussion } 2\end{array}$} \\
\hline & No. & $\%$ & No. & $\%$ & No. & $\%$ & No. & $\%$ \\
\hline 0 & 6 & $5 \%$ & 29 & 22 & 32 & 25 & 1 & $1 \%$ \\
\hline 1 & 110 & $85 \%$ & 90 & 70 & 93 & 72 & 92 & $71 \%$ \\
\hline 2 & 10 & $8 \%$ & 10 & 8 & 3 & 2 & 31 & $24 \%$ \\
\hline 3 & 3 & $2 \%$ & 0 & 0 & 1 & 1 & 5 & $4 \%$ \\
\hline
\end{tabular}

\section{Performance in Assessment Task}

The Table 6 depicts the outcome of the performance of learners in a Course A and Course B respectively. Grading the cohort of learners in course A compared with performance Cohort of Course B reveals that for course A about $8 \%$ scored below average while $70 \%$ performed above average for Discussion 1 while about $64 \%$ performed above average for Discussion 2 . In Course B, 29\% and $20 \%$ of the learners scored above average in discussion 1 and 2 respectively. 
Table 6: Performance in Assessment Task

\begin{tabular}{|l|l|l|l|l|}
\hline \multicolumn{2}{|c|}{ performance in assessment } \\
\hline & \multicolumn{2}{|c|}{ Course A } & \multicolumn{2}{c|}{ Course B } \\
\hline Performance & $\begin{array}{l}\text { Discussion 1: } \\
\text { (\%)Learners } \\
\text { Number }\end{array}$ & $\begin{array}{l}\text { Discussion 2: } \\
(\%) \text { Learners } \\
\text { Number }\end{array}$ & $\begin{array}{l}\text { Discussion 1: } \\
\text { (\%)Learners } \\
\text { Number }\end{array}$ & $\begin{array}{l}\text { Discussion 2: } \\
\text { (\%)Learners } \\
\text { Number }\end{array}$ \\
\hline below average & $8 \%$ & $5 \%$ & 30 & 20 \\
\hline Average & $22 \%$ & $31 \%$ & 41 & 60 \\
\hline satisfactory & $40 \%$ & $41 \%$ & 27 & 13 \\
\hline distinction & $30 \%$ & $23 \%$ & 2 & 7 \\
\hline
\end{tabular}

From Table 7, the analysis was made according to how well the learners participated online. Course A show more vibrant and aggressive participation when compared to Course B.

Table 7: Break down of Behavioural patterns for Courses A and B

\begin{tabular}{|c|c|c|c|c|c|c|c|c|c|c|c|}
\hline $\begin{array}{l}\text { Confide } \\
\text { nce }\end{array}$ & $\begin{array}{l}\text { Course } \\
\text { A Log. }\end{array}$ & $\begin{array}{l}\text { Cours } \\
\text { e B } \\
\text { Log. }\end{array}$ & Effort & $\begin{array}{l}\text { Course } \\
\text { A Log }\end{array}$ & $\begin{array}{l}\text { Course } \\
\text { B Log }\end{array}$ & $\begin{array}{l}\text { Indepen } \\
\text { dence }\end{array}$ & $\begin{array}{l}\text { Course } \\
\text { A Log }\end{array}$ & $\begin{array}{l}\text { Course } \\
\text { B Log }\end{array}$ & $\begin{array}{l}\text { Confusi } \\
\text { on }\end{array}$ & $\begin{array}{l}\text { Course } \\
\text { A Log }\end{array}$ & $\begin{array}{l}\text { Course } \\
\text { B Log }\end{array}$ \\
\hline $\begin{array}{l}\text { contntvi } \\
\text { sit }\end{array}$ & 90 & 45 & $\begin{array}{l}\text { slfasse } \\
\text { ssvisit }\end{array}$ & 211 & 190 & $\begin{array}{l}\text { contntvis } \\
\text { it }\end{array}$ & 90 & 45 & $\begin{array}{l}\text { slfassess } \\
\text { visit }\end{array}$ & 211 & 45 \\
\hline $\begin{array}{l}\text { outlinev } \\
\text { isit }\end{array}$ & 33 & 21 & $\begin{array}{l}\text { slfasse } \\
\text { ssstay }\end{array}$ & 133 & 121 & $\begin{array}{l}\text { outlinevi } \\
\text { sit }\end{array}$ & 33 & 21 & $\begin{array}{l}\text { exercsvi } \\
\text { sit }\end{array}$ & 213 & 21 \\
\hline $\begin{array}{l}\text { Exampl } \\
\text { evisit }\end{array}$ & 823 & 530 & $\begin{array}{l}\text { exercs } \\
\text { visit } \\
\end{array}$ & 213 & 115 & $\begin{array}{l}\text { examplev } \\
\text { isit }\end{array}$ & 823 & 530 & $\begin{array}{l}\text { example } \\
\text { visit }\end{array}$ & 823 & 530 \\
\hline $\begin{array}{l}\text { exercsvi } \\
\text { sit }\end{array}$ & 213 & 115 & $\begin{array}{l}\text { exercs } \\
\text { stay }\end{array}$ & 322 & 206 & $\begin{array}{l}\text { forumcon } \\
\text { tntvisit }\end{array}$ & 700 & 600 & $\begin{array}{l}\text { example } \\
\text { stay }\end{array}$ & 0 & 600 \\
\hline $\begin{array}{l}\text { Slfasses } \\
\text { svisit }\end{array}$ & 211 & 211 & $\begin{array}{l}\text { forum } \\
\text { contnt } \\
\text { visit }\end{array}$ & 700 & 600 & $\begin{array}{l}\text { forumcon } \\
\text { tntpost }\end{array}$ & 2 & 2 & $\begin{array}{l}\text { forumas } \\
\text { signmnt } \\
\text { post }\end{array}$ & 2 & 2 \\
\hline $\begin{array}{l}\text { Forumc } \\
\text { ontntpo } \\
\text { st }\end{array}$ & 2 & 2 & $\begin{array}{l}\text { forum } \\
\text { contnt } \\
\text { postre } \\
\text { pl }\end{array}$ & 308 & 212 & $\begin{array}{l}\text { forumcon } \\
\text { tntpostre } \\
\text { pl }\end{array}$ & 308 & 212 & $\begin{array}{l}\text { Assign } \\
\text { mntrevi } \\
\text { sion }\end{array}$ & 24 & 212 \\
\hline $\begin{array}{l}\text { forumco } \\
\text { ntntpost } \\
\text { reply }\end{array}$ & 308 & 212 & $\begin{array}{l}\text { assign } \\
\text { mnt } \\
\text { revisi } \\
\text { on }\end{array}$ & 24 & 2 & $\begin{array}{l}\text { assignmn } \\
\text { trevision }\end{array}$ & 24 & 2 & $\begin{array}{l}\text { contntst } \\
\text { ay }\end{array}$ & 57 & 2 \\
\hline $\begin{array}{l}\text { forumas } \\
\text { signmnt } \\
\text { visit }\end{array}$ & 593 & 400 & & & & $\begin{array}{l}\text { slfassessv } \\
\text { isit }\end{array}$ & 211 & 190 & $\begin{array}{l}\text { forumco } \\
\text { ntntvisit }\end{array}$ & 700 & 190 \\
\hline \multirow[t]{4}{*}{$\begin{array}{l}\text { Forumc } \\
\text { ontntvis } \\
\text { it } \\
\end{array}$} & 700 & 600 & & & & $\begin{array}{l}\text { slfassesss } \\
\text { tay }\end{array}$ & 133 & 121 & $\begin{array}{l}\text { forumco } \\
\text { ntntpost } \\
\text { repl }\end{array}$ & 308 & 121 \\
\hline & & & & & & $\begin{array}{l}\text { slfassessr } \\
\text { evision }\end{array}$ & 43 & 5 & & & 5 \\
\hline & & & & & & $\begin{array}{l}\text { exercsvisi } \\
t\end{array}$ & 213 & 115 & & & 115 \\
\hline & & & & & & $\begin{array}{l}\text { exercssta } \\
\mathrm{y}\end{array}$ & 322 & 206 & & & 206 \\
\hline TOTAL & 2973 & 2136 & & 1911 & 1446 & & 2902 & 2049 & & 2338 & 2049 \\
\hline
\end{tabular}


In order to determine whether the learners' affect-adaptive states would affect learning performance or not, the analysis was done using statistical tool and presented in Table 8 for both course A and Course B. Mean and Standard Deviation (SD) were calculated according to the four(4) states (Confidence, Effort, Independence and Confusion). Confidence state had the highest values among all others with Mean=330.00 and $S D=302.25$ for course A and Mean=237.33 and SD=223.36 for course B. This confidence value showed that learning performance can be influenced either positively or negatively by confidence state. The Confusion states also had a value with Mean=259.78 and $\mathrm{SD}=305.89$ for course A and Mean=187.67 and $\mathrm{SD}=229.31$ for course B. The confusion values show that confused learners participate less on the learning platform. The higher average mean and standard deviation (SD) value for Course A (Mean=276.23, SD=272.27) over Course B (Mean=200.58, $\mathrm{SD}=210.51$ ) shows an improvement in learning performance. Also, a t-Test analysis was carried out to test the statistical significance difference. The test confirms that the difference was significant and the t-Test result suggested learners' performance was dependent on their affect-adaptive states.

Table 8. Statistical details of learners' Affect-Adaptive states

\begin{tabular}{|l|c|c|c|c|c|c|c|}
\hline & & & & & & & \\
\hline Affect states & \multicolumn{2}{|c|}{ Course A } & \multicolumn{2}{c|}{ Course B } & \multicolumn{2}{|c|}{ t TEST } & \\
\hline & Mean & SD & Mean & SD & T Stat & $\mathrm{p}$ & $\mathrm{d}$ \\
\hline Confidence & 330.33 & 302.25 & 237.33 & 223.36 & 2.858 & 0.021 & 8 \\
\hline Effort & 273 & 214.09 & 206.57 & 188.26 & 3.857 & 0.008 & 7 \\
\hline Independence & 241.83 & 266.85 & 170.75 & 201.11 & 3.039 & 0.011 & 11 \\
\hline Confusion & 259.78 & 305.89 & 187.67 & 229.31 & 2.342 & 0.047 & 8 \\
\hline $\begin{array}{l}\text { AVERAGE } \\
\text { VALUE }\end{array}$ & $\mathbf{2 7 6 . 2 3}$ & $\mathbf{2 7 2 . 2 7}$ & $\mathbf{2 0 0 . 5 8}$ & $\mathbf{2 1 0 . 5 1}$ & & & \\
\hline
\end{tabular}

\section{Conclusion}

This research work was conducted to identify learners' affect-adaptive states and see how learning performances can be improved using these states in a personalised ubiquitous learning system. The use of ubiquitous technology makes accessibility to education resources available at anywhere and anytime. Considering adaptability, personalisation and ubiquity, this research paper investigates learners' affective states such as confidence, effort, independence and confusion when learning. Trilateration and fingerprint techniques are both used to determine the learners' locations. The learners' preference is determined using Felder Silverman learning style dimensions based on learners' activities in online learning process. The ant colony clustering algorithm is used to determine learners' activities. The four affective states are determined from the learners' forum threads, content activities, assessment, timing, and discussion through learners' engagement. The result of the study suggests that performance of learners improves when learners' affective states are considered during learning. 


\section{Acknowledgement}

The research is sponsored by Tertiary Education Trust Fund (TETFUND) in the context of "Personalised Adaptive Ubiquitous Learning System" under the National Research and Innovation Grant.

\section{References}

Adewale O. S. (2007), University Digital Libraries: adaptive, personalised e-learning system, Yerimah Prints, ISBN: 978-38410-2-5

Baker, R. S. J. D. (2010). Data mining for education. International encyclopedia of education, 7(3), 112-118.

Baker, R. S., D'Mello, S. K., Rodrigo, M. M. T., \& Graesser, A. C. (2010). Better to be frustrated than bored: The incidence, persistence, and impact of learners' cognitive-affective states during interactions with three different computerbased learning environments. International Journal of Human-Computer Studies, 68(4), 223-241.

Becker-Asano, C., \& Wachsmuth, I. (2010). Affective computing with primary and secondary emotions in a virtual human. Autonomous Agents and Multi-Agent Systems, 20(1), 32.

Behera, S. K. (2013). E-and M-Learning: A comparative study. International Journal on New Trends in Education and Their Implications, 4(3), 65-78.

Beldagli, B. \& Adiguzel, T. (2010). “Illustrating an ideal adaptive e-learning: a conceptual framework," in Proceedings of the 2nd World Conference on Educational Sciences (WCES '10), pp. 5755-5761.

Bennet, A., \& Bennet, D. (2008). E-Learning as energetic learning. VINE, 38(2), 206-220.

Besterfield-Sacre, M., Amaya, N.Y., Shuman, L. J., Atman, C.J., \& Porter, R. (1998). Understanding student confidence as it relates to first year achievement", Frontiers in Education Conference, November, pp 258-263

Brown, T. H., \& Mbati, L. S. (2015). Mobile learning: Moving past the myths and embracing the opportunities. The international review of research in open and distributed learning, 16(2).

Callaghan, V., Shen, L., Gardner, M., Shen, R., \& Wang, M. (2009). A mixed reality approach to hybrid learning in mixed culture environments. Handbook of Research on Hybrid Learning Models: Advanced Tools, Technologies, and Applications: Advanced Tools, Technologies, and Applications, 260.

Casey, D(2005). In E-Learn 2005-World Conference on E-Learning in Corporate, Government, Healthcare, and Higher Education; Richards, G., Ed.; Association for the Advancement of Computing in Education (AACE): Vancouver, BC, Canada, 2005; pp. 2864-2871.

D’Mello, S.K., Lehman, B., Pekrun, R., \& Graesser, A.C (2014). Confusion can be beneficial for learning. Learn. Instr. 29(1), 153-170.

Doukhnitch, E., Salamah, M., \& Ozen, E (2008). An efficient approach for trilateration in 3D positioning, Computer Communications, 31(17), 4124-4129.

Entwistle, N., \& Ramsden, P. (2015). Understanding student learning (Routledge revivals). Routledge.

Farman, A.K., Sabine, G., Edgar, R. W., \& A Min T. (2010). Identifying and incorporating affective states and learning styles in web-based learning management systems, Interaction Design and Architecture(s) Journal, vol. 9, no. 10, pp. 85-103.

Fasihuddin, H., Skinner, G., \& Athauda, R. (2017). Towards adaptive open learning environments: Evaluating the precision of identifying learning styles by tracking learners' behaviours. Education and Information Technologies, 22(3), 807-825. 
Feidakis, M., Caballé, S., Daradoumis, T., Jiménez, D. G., \& Conesa, J. (2014). Providing emotion awareness and affective feedback to virtualised collaborative learning scenarios. International Journal of Continuing Engineering Education and Life Long Learning 6, 24(2), 141-167.

Felder, R. M., \& Silverman, L. K. (1988), Learning and teaching styles in engineering education, Engineering Education, 78(7): 674-681

Hsu, T.Y., Chiou, C.K., Tseng, J.C.R., \& Hwang, G.J. (2016). Development and Evaluation of an Active Learning Support System for Context-Aware Ubiquitous Learning. IEEE Trans. Learn. Technol. 2016, 9, 37-45.

Hu, X.H., Mu, T., Dai, W.H., Hu, H.Z., \& Dai, G.H(2012). Analysis of browsing behaviors with ant colony clustering algorithm. Journal of Computers 7(12), 3096-3102.

Hwang, G.-J., Tsai, C.-C., \& Yang, S.J.H. (2008). Criteria, Strategies and Research Issues of Context-Aware Ubiquitous Learning. J. Educ. Technol. Soc., 11, 81-91.

Jones, V., \& Jo, J. H. (2004). Ubiquitous learning environment: An adaptive teaching system using ubiquitous technology. In R. Atkinson, C. McBeath, D. JonasDwyer, \& R. Phillips (Eds.), Proceedings of the 21st ASCILITE (Australasian Society for Computers in Learning in Tertiary Education) Conference (pp. 468e474). Perth, Australia: ASCILITE.

Kalyuga, S. (2011). Cognitive load theory: Implications for affective computing. Paper presented at the FLAIRS Conference.

Keltner, D., \& Shiota, M.N. (2003), New displays and new emotions: A commentary on Rozin and Cohen (2003) Emotion, 3(1): 86-91

Khan, F. A., Graf, S., Weippl, E. R., \& Tjoa, A. M. (2010). Identifying and Incorporating Affective States and Learning Styles in Web-based Learning Management Systems. IxDEA, 9, 85-103.

Khan, F. A., Weippl, E. R., \& Tjoa, A. M. (2009). Integrated Approach for the detection of learning styles and affective states. In World Conference on Educational Multimedia, Hypermedia and Telecommunications, (1), 753-761.

Kim, S. B. (2006). Cyber communication \& ubiquitous language learning: Feasibility \& reality with reference to survey research. Multimedia Assisted Language Learning, 7(3), 9-45.

Kirschner, P. A., Sweller, J., \& Clark, R. E. (2006). Why minimal guidance during instruction does not work: An analysis of the failure of constructivist, discovery, problem-based, experiential, and inquiry-based teaching. Educational psychologist, 41(2), 75-86.

Kort, B., Reilly, R., Picard, R.W. (2001). An affective model of the interplay between emotions and learning. In: Proceedings of the IEEE International Conference on Advanced Learning Technologies (ICALT ‘01). IEEE Computer Society, pp. 4346.

Lin, P., Li, Q., Fan, Q., Gao, X., \& Hu, S. (2014). A real-time location-based services system using WiFi fingerprinting algorithm for safety risk assessment of workers in tunnels. Mathematical Problems in Engineering, 2014.

Liyanage, M. P. P., KS, L. G., \& Hirakawa, M. (2016). Detecting learning styles in learning management systems using data mining. Journal of Information Processing, 24(4), 740-749.

Lopatovska, I., \& Arapakis, I. (2011). Theories, methods and current research on emotions in library and information science, information retrieval and humancomputer interaction. Information Processing \& Management, 47(4), 575-592.

López-Pérez, M. V., Pérez-López, M. C., \& Rodríguez-Ariza, L. (2011). Blended learning in higher education: Students' perceptions and their relation to outcomes. Computers \& education, 56(3), 818-826. 
Marczak, M., Krajka, J., \& Malec, W. (2016). Web-based assessment and language teachers-from Moodle to WebClass. International Journal of Continuing Engineering Education and Life Long Learning, 26(1), 44-59.

Moore, M. G., \& Kearsley, G. (2011). Distance education: A systems view of online learning. Cengage Learning.

Paramythis, A. \& Loidl-Reisinger, S. (2004). Adaptive learning environments and elearning standards. Electronic Journal of eLearning, 2(1), March. http://www.ejel.org/volume-2/vol2-issue1/issue1-art11.htm

Pintrich, P.R. \& DeGroot, E.V. (1990), Motivational and self-regulated learning components of classroom academic performance, Journal of Educational Psychology, 82: pp. 33-40.

Premlatha, K. R., Dharani, B., \& Geetha, T. V. (2016). Dynamic learner profiling and automatic learner classification for adaptive e-learning environment. Interactive Learning Environments, 24(6), 1054-1075.

Qu, L., Wang, N., Johnson \& Lewis, W. (2005). Using Learner Focus of Attention to Detect Learner Motivation Factors, In Ardissono, L., Brna, P., Mitrovic, A.: User Modelling, pp 70-73.

Rozin, P. \& Cohen, A.B. (2003a). Confusion infusions, suggestives, correctives, and other, medicines, Emotion, 3: 92-96

Sadoun, B. \& Al-Bayari, O. (2007). Location based services using geographical information systems, Computer Communications, 30(16), .3154-3160.

Sangineto, E., Capuano, N., Gaeta, M., \& Micarelli, A. (2008), Adaptive course generation through learning styles representation, Journal of Universal Access in the Information Society 7(1), 1-23.

Setiya, R., \& Gaur A. (2012). Location fingerprinting of mobile terminals by using Wi-Fi device, International Journal of Advanced Research in Computer Engineering \& Technology, 1(4), 311-314.

Siadaty, M. \& Taghiyareh, F. (2007). PALS2: Pedagogically Adaptive Learning System based on Learning Styles, Seventh IEEE International Conference on Advanced Learning Technologies (ICALT), pp.616-618.

Sung, Y. T., Chang, K. E., \& Liu, T. C. (2016). The effects of integrating mobile devices with teaching and learning on students' learning performance: A meta-analysis and research synthesis. Computers \& Education, 94, 252-275.

Tortorella, R. A., \& Graf, S. (2017). Considering learning styles and context-awareness for mobile adaptive learning. Education and Information Technologies, 22(1), 297-315.

Tummala, H., and Jones, J. (2005). Developing spatially-aware content management systems for dynamic, location-specific information in mobile environments. The 3rd ACM International Workshop on Wireless Mobile Applications and Services on WLAN Hotspots (pp. 14-22).

Wang, H. Y., Liu, G. Z., \& Hwang, G. J. (2017). Integrating socio- cultural contexts and location- based systems for ubiquitous language learning in museums: A state of the art review of 2009-2014. British Journal of Educational Technology, 48(2), 653671.

Wanner, T., \& Palmer, E. (2015). Personalising learning: Exploring student and teacher perceptions about flexible learning and assessment in a flipped university course. Computers \& Education, 88, 354-369.

Wong, L. H., Milrad, M., \& Specht, M. (Eds.). (2015). Seamless learning in the age of mobile connectivity. Singapore: Springer.

Yahya, S., Ahmad, E.A., \& Jalil, K.A. (2010). The definition and characteristics of ubiquitous learning: A discussion. Int. J. Educ. Dev. Using Inf. Commun. Technol., 6, 117-127. 
Yin, P.-Y., Chuang, K.-H., \& Hwang, G.-J. (2016). Developing a context-aware ubiquitous learning system based on a hyper-heuristic approach by taking real-world constraints into account. Univers. Access Inf. Soc., 15, 315-328.

Yuan, L., Powell, S., \& CETIS, J. (2013). MOOCs and open education: Implications for higher education.

Zimmerman, B. J. (2013). Theories of self-regulated learning and academic achievement: An overview and analysis. In Self-regulated learning and academic achievement (pp. 10-45). Routledge. 